ROCZNIKI PEDAGOGICZNE

Tom 11(47), numer 2 - 2019

DOI: http://dx.doi.org/10.18290/rped.2019.11.2-5

S. IWONA LIS

\title{
PRZESTRZEŃ AKSJOLOGICZNA W NAUCZANIU RELIGII DZIECI W WIEKU WCZESNOSZKOLNYM
}

Wartości w życiu człowieka odgrywają szczególną rolę. Są one wyznacznikiem naszych życiowych wyborów, dążeń, wpływają na rozwój osobowości ucznia. Za wartość uznaje się „,wszystko, co cenne i godne pożądania, co stanowi cel ludzkich działań" (Schrade, 1992, s. 50).

Należy podkreślić, iż istota człowieczeństwa zawiera się w uznaniu wartości człowieka jako osoby, jej godności, wolności, rozumności, integralności wymiaru fizycznego, psychicznego, duchowego, odpowiedzialności za podejmowane działania, w kreowaniu siebie $\mathrm{w}$ aspekcie transcendencji. W rozwoju człowieka szczególną rolę pełnią te wartości, które prowadzą do głębszego poznania życia duchowego (Chałas, 2003). W tym aspekcie na uwagę zasługują wartości chrześcijańskie, ponieważ „człowiek przyjmujący naukę Chrystusa powinien całkowicie poświęcić się i zaangażować na rzecz podstawowej wartości, jaką jest zbawienie. Tak widziana wartość podstawowa transcenduje, przekracza i przechodzi przez wszelkie wartości” (Oleś, 1993, s. 63). Zatem w jaki sposób w edukacji wczesnoszkolnej możemy wprowadzać ucznia w świat wartości? Jakie podstawowe wartości chrześcijańskie są przekazywane na tym etapie edukacyjnym? W jaki sposób nauczanie religii w szkole jest tym obszarem, w którym rozwija się przestrzeń aksjologiczna małego dziecka?

Człowiek jest ze swojej natury osobą społeczną, dlatego też szkoła to ta wspólnota, dzięki której kształtuje się w dziecku poczucie przynależności nie tylko do świeckich obszarów życia: rodziny, szkoły, grupy rówieśniczej, ale dzięki nauczaniu religii także tych, połączonych z życiem wiary i jej wartościami. Stanowi to wsparcie dla podstawy rozwoju człowieka, jego dojrzałości społecznej i religijnej. Uczeń podejmuje na płaszczyźnie wspólnoty szkolnej,

S. mgr IwONA LIS - doktorantka, Katedra Dydaktyki i Edukacji Szkolnej, Instytut Pedagogiki Katolickiego Uniwersytetu Lubelskiego Jana Pawła II; e-mail: iwonalis69@gmail.com 
klasowej pierwsze próby budowania kontaktu z rówieśnikami, zaspokajania potrzeby wzajemnej akceptacji, przyjaźni, oddania, służby i miłości do drugiego człowieka. Nauczanie religii w edukacji wczesnoszkolnej obejmuje zarówno procesy edukacji, jak i wychowania do wartości, co ma na celu formowanie takich postaw życiowych wychowanka, ucznia, aby był w swoim życiu jednostką dojrzałą emocjonalnie, społecznie i duchowo.

$\mathrm{Na}$ bazie wychowania do wartości może się rozwijać życie wspólnotowe, społeczne ucznia i wychowanka. Pozwala to na wytworzenie więzi ja-Bóg, a następnie, w odniesieniu do tej wspólnoty, budowanie relacji w klasie, szkole, rodzinie i społeczeństwie. „Szkoła powinna bowiem uczyć stawiania samodzielnych pytań egzystencjalnych i poszukiwania na nie odpowiedzi” (Milerski, 2010, s. 62). W nauczaniu religii w edukacji wczesnoszkolnej chodzi o takie wprowadzenie ucznia w świat wartości, aby stawiając pytania: Kim jestem? Dokąd zmierzam? Kim mogę się stać? Kim powinienem być? Jaki jest sens i cel mojego życia?, potrafił udzielić na nie odpowiedzi oraz je urzeczywistnił w życiu dając świadectwo (Chałas, 2009).

W wychowaniu religijnym za J. Wilkiem - możemy wyróżnić trzy fazy: obudzenie, rozwinięcie i dopełnienie. Fazy te możemy zaobserwować u uczniów klas I-III w procesie nauczania religii. Dziecko, rozpoczynające naukę w szkole podstawowej, jest na etapie fazy obudzenia, u podstaw której stoją relacje osobowe z rodzicami. Relacje pozytywne przekazywane w rodzinie, zwłaszcza gdy ich podstawą jest wzajemna miłość, pozwalają dziecku kształtować w sobie postawę dobra i otwartości na Boga. W fazie rozwoju dziecko głównie uczestniczy w życiu religijnym dorosłych, obserwując ich postawy religijne i wyznawane przez nich wartości, dlatego też ważna na tym etapie jest postawa rodziców, którzy są największym autorytetem dla dziecka, są jego wychowawcami.

Etap trzeci to ten, w który głównie wpisuje się edukacja wczesnoszkolna. Nauczyciel-katecheta wezwany jest do przekazania dziecku idei Boga oraz wartości, jakie niesie głębsze poznawanie Go. Dziecko, prowadzone przez rodziców i nauczyciela, rozpoznaje i odczytuje znaki istnienia Boga w otaczającej go rzeczywistości, relacjach i w świecie. W tym czasie dziecko przygotowuje się także do przyjęcia kolejnych sakramentów wprowadzających w życie chrześcijańskie: sakramentu pokuty i pojednania oraz Eucharystii, zaczyna także prowadzić pod opieką rodziców i katechetów pełniejsze życie religijne, uczestnicząc w przygotowaniach i poznając nowe wartości. Ważnym zadaniem dla nauczyciela będzie tutaj kształtowanie $\mathrm{w}$ wychowanku odniesienia do prawd wiary tak, aby konsekwencją tego postępowania edukacyjnego było doświadczenie życia Bożego i świadome uczestnictwo w życiu Boga poprzez życie sakramentalne. 
Zatem, w toku edukacji religijnej dzieci w wieku wczesnoszkolnym przed nauczycielem stoją cztery zadania do zrealizowania, aby ukazać dziecku wartości religijne jako:

- uczestnictwo w życiu Boga;

- przylgnięcie do Chrystusa;

- oparcie się na Chrystusie;

- uznanie własnej bezradności i oczekiwanie wszystkiego od Boga (Chałas, 2009).

Jak każdy proces wychowawczy, tak i wychowanie do wartości religijnych u swego początku powinno mieć poznanie ucznia jako podmiotu oddziaływania poczynań wychowawczych. Dzięki temu w edukacji wczesnoszkolnej nauczycielkatecheta wezwany jest do takiego doboru treści, metod, środków i działań interpersonalnych, aby proces dydaktyczno-wychowawczy przyniósł oczekiwane efekty. Należy dzieciom w taki sposób przybliżyć i przekazać określone wartości religijne, aby ich poznanie stanowiło podstawowy warunek ich akceptacji, internalizacji i wolnego wyboru, do którego ma zmotywować wychowawca (Chałas, 2009). Nauczyciel-katecheta ma być tym, który posiadając wiedzę o wartościach religijnych będzie wspomagał, motywował wychowanka do ich zdobywania i urzeczywistniania. Wzorem dla wychowanka będzie sam nauczyciel i spektrum urzeczywistnianych w jego życiu wartości, stanowiąc w ten sposób dla ucznia niezbywalny autorytet w ukazywaniu wychowankowi drogi do głębi człowieczeństwa. Wykorzystując strategię świadectwa, u podstaw której leży identyfikacja z wartościami osoby znaczącej, wychowawca pomaga wychowankowi w nabywaniu i przyswojeniu sobie takich samych wartości, które ukazują życie nauczyciela zgodne z deklarowanymi wartościami. Za K. Chałas (2003, s. 104) możemy powiedzieć, że strategia ta implikuje dla wychowawcy zadanie poszerzania formatu własnego człowieczeństwa, stawania się autorytetem, tak by poprzez głębi człowieczeństwa poruszyć umysł i serce wychowanka, by wzbudzić w nim wewnętrzne siły kształtujące jego zachowanie. M. Nowak podkreśla, że rezultatem działania wychowawczego jest pełna realizacja własnej osoby - dojrzała osobowość zdolna komunikować się i wchodzić w interakcję społeczną. Proces ten polega na stawianiu wymagań i zadań na miarę możliwości dziecka, jego umiejętności i zdolności. Należy uświadomić mu, że posiada talenty i uzdolnienia do tego, aby osiągnąć pełnię człowieczeństwa i dojrzałą osobowość (Nowak 1999, s. 290).

Wychowując do wartości należy wziąć pod uwagę różne etapy osiągania kompetencji aksjologicznych (Wołosiuk, 2010). U. Ostrowska (2006, s. 413) uporządkowała je w następujący sposób: 
- Odkrywanie i rozpoznawanie wartości (wymagana jest zdolność rozpoznawania dobra i zła przez dziecko, zauważania tego, co cenne);

- Rozumienie wartości (potrzebna jest wiedza o wartościach oraz zdolność logicznego myślenia);

- Uznawanie i akceptowanie wartości (dziecko powinno przyjmować wartości jako własne);

- Urzeczywistnianie wartości (wymagana jest konsekwencja, jeśli chodzi o zakres przyjętych zobowiązań w świecie wartości);

- Tworzenie wartości (wymagana jest aktywność twórcza).

Jak zauważa dalej Ostrowska, zadaniem nauczyciela jest takie przygotowanie ucznia do dorosłego życia, aby poprzez przekazywaną wiedzę, własną postawę wprowadził go w świat wartości. Wychowawca swoim życiem i postępowaniem wyjaśnia dziecku na czym polegają i jak się realizuje w życiu poszczególne wartości. Bardzo ważne są tu metody prowadzenia zajęć, odpowiednio dobrane środki dydaktyczne, a także zaangażowanie ucznia zmotywowanego postawą nauczyciela.

Wskazanym i niezbędnym jest zachęcanie dzieci do samodzielnych wyborów, praca zadaniowa mająca na celu odnajdywanie oraz realizowanie $\mathrm{w}$ praktyce poznawanych i nabywanych w toku procesu edukacyjno-wychowawczego wartości. W tym kontekście dziecko będzie mogło osobiście odnaleźć i bezpośrednio doświadczyć w otaczającym świecie tych wartości, które w konsekwencji przyjmie jako własne (Malicka, 2002).

Analizując sposób przekazywania wartości w procesie edukacyjno-wychowawczym, warto także zwrócić uwagę na zagadnienie klaryfikacji. Twórcy tej koncepcji (L.E. Raths, M. Harmin, S.B. Simon) uważają, iż wychowanek-uczeń dokona mądrych wyborów, jeśli zostanie mu zapewniony odpowiedni klimat w procesie edukacyjnym. Klimat ten - według twórców koncepcji - to: poczucie bezpieczeństwa, akceptacja i współpraca. W procesie wartościowania kształtuje się system wartości wychowanka. Na proces ten składają się:

- Wolny wybór;

- Wybieranie spośród alternatywnych możliwości;

- Opowiadanie się za wyborem po rozważeniu konsekwencji każdej z nich;

- Akceptowanie wartości cennych dla ucznia;

- Pozytywne ocenianie wartości wybranych w sposób wolny;

- Postępowanie zgodne z wyborem wartości;

- Konsekwentne orientowanie się zgodnie z wybranymi wartościami w różnych sytuacjach i zachowaniach ( Denek, 2005, s. 134). 
Nauczyciel chcąc, aby dziecko nauczyło się dokonywać właściwego wyboru wartości, powinien jak najwcześniej wdrażać je do poznania ich, zważając na to, iż jest to proces długi i jego sukces będzie uwarunkowany ilością czasu, jaki został poświęcony dziecku, aby wprowadzić je w świat wartości. Im bardziej przekaz ten będzie przez dzieci odkrywany i akceptowany, tym większe są szanse, że dziecko ten świat wartości uzna za swój i będzie go potrafiło urzeczywistnić w swoim codziennym życiu, a w przyszłości w pracy zawodowej, postawach rodzicielskich i obywatelskich.

Jeśli proces ten zostanie realizowany $\mathrm{w}$ stopniu niewystarczającym lub zakłócony przez czynniki negatywne, np. brak komunikacji, brak autorytetu ze strony rodziców i nauczyciela, osądzanie dziecka i jego postaw, dawanie gotowych rozwiązań, unikanie, brak zaangażowania, to hierarchię wartości małego dziecka ukształtują inne czynniki. Jednym z nich, silnie działającym na osobowość dziecka, mogą być środki masowego przekazu z promowanym przez nie konsumpcyjnym stylem życia. B. Wołosiuk (2012) wskazuje również na konflikty rodzinne jako czynniki negatywne zaburzające komunikację interpersonalną, tym samym utrudniając wprowadzanie dzieci w wieku wczesnoszkolnym w przestrzeń aksjologiczną.

Sytuacje wychowawcze poprzez wyznaczone cele, treści, metody i zadania wychowawcze są doskonałą okazją do wprowadzania dziecka w świat wartości religijnych. Jak każdy przedmiot nauczania, tak i katecheza w sposób szczególny posiada swoją warstwę aksjologiczną, odgrywającą ogromne znaczenie w procesie wychowania ku wartościom i rozszerzaniu horyzontu aksjologicznego dzieci w wieku wczesnoszkolnym.

Należy zatem tak prowadzić edukację katechetyczną, aby jak najpełniej wydobyć tę warstwę poprzez sytuacje edukacyjno-wychowawcze podczas lekcji religii w klasach I-III. Będą to często zadania wymagające od uczniów aktywnego zaangażowania, podjęcia określonego działania prowadzącego do poznania, odkrywania, wyjaśniania, wartościowania, projektowania, wykonania, autokreacji, animacji ( Chałas, 2003).

Wartości religijne odgrywają znaczącą rolę w kształtowaniu dojrzałej osobowości ucznia-wychowanka. Jego integralny rozwój S. Kunowski określa jako względnie równomierny rozwój poszczególnych warstw jego życia i funkcjonowania, tj. warstwy biologicznej, psychologicznej, socjologicznej, kulturowej, duchowej oraz ich wzajemną integrację (Kunowski, 2004, s. 197). We wprowadzaniu ucznia w świat wartości religijnych podstawową jest funkcja chrystianisare, która ma doprowadzić wychowanka do osobowego spotkania z Chrystusem 
i życia według Jego nauki, wprowadzając i urzeczywistniając w codzienności wartości poznane i zaakceptowane. Funkcja ta łączy w sobie wszystkie pozostałe, przypisując im jeszcze większe znaczenie.

„Funkcja sanare jest tu widziana jako uzdrawiające działanie łaski, leczące skażoną naturę ludzką i dające poczucie wolności dzieci Bożych.

Funkcja edocere to prowadzenie do Boga, źródła prawdy i budzenie świadomości wiary.

Funkcja educere - wprowadzenie wychowanka do społeczności wiernych w Kościele i włączenie go do apostolatu.

Funkcja educare - wprowadzenie wychowanka na drogę naśladowania Chrystusa, który jest «personalnym symbolem wartości» i uosobieniem najwyższego ideału człowieka.

Funkcja initiare jest pojmowana w chrześcijaństwie jako wprowadzenie w sakramenty wtajemniczenia chrześcijańskiego i światopogląd chrześcijański" (Nowak, 2008, s. 310).

Podstawowym warunkiem dochodzenia do wartości religijnych jest dla ucznia-wychowanka umiejętność wartościowania. Rozwój moralny dziecka dokonuje się etapowo. W literaturze możemy znaleźć usystematyzowane etapy rozwoju moralnego według J. Piageta i L. Kohlberga. M. Łobocki, analizując stanowiska powyższych autorów mówi, że podstawą wyodrębnienia faz w rozwoju moralnym przez J. Piageta ,jest sposób, w jaki dzieci odnoszą się do reguł stosowanych szczególnie $\mathrm{w}$ grach i zabawach dziecięcych, a także w różnych codziennych sytuacjach życiowych”( Łobocki, 2002, s. 46).

J. Piaget wyróżnia cztery stadia rozwoju moralnego dzieci:

1) Stadium anomii przypada na okres 0 - 2 r. ż. dziecka. Dziecko w tej fazie rozwoju nie odczuwa obowiązku przestrzegania jakichkolwiek reguł postępowania włączając postępowanie moralne. Dziecko w tej fazie - pisze M. Łobocki - jest ,amoralne, czyli pozbawione możliwości rozumienia i oceny jakichkolwiek reguł" ( Tamże).

2) Stadium realizmu moralnego (lub egocentryzmu) to okres od 2 do $7 \mathrm{r}$. $\dot{z}$. „W stadium tym, dzieci jakiekolwiek reguły, a więc także reguły moralne, traktują jako obowiązujące w sposób bezwzględny" (Tamże, s. 56). Dzieci w tym stadium wszelkie reguły moralne traktują jako bezwzględnie niezmienne, autorytatywne.

3) Trzecie stadium rozwoju moralnego to faza relatywizmu moralnego. Charakteryzują się nią dzieci w wieku 7-11 lat, które ,nabierają stopniowo przekonania o tym, że reguły moralne są umowami zawieranymi przez ludzi, celem przychodzenia im z pomocą i służenia sobie nawzajem" (Tamże, s. 57). 
4) Czwartym stadium jest stadium autonomii (ok. 12 roku życia). „W stadium tym dzieci stają się coraz bardziej krytyczne wobec reguł narzuconych im przez dorosłych. Reguł tych nie przestrzegają już jedynie po to, by nie narażać się na ponoszenie sankcji lub też $\mathrm{w}$ przekonaniu, że nigdy nie można wysnuwać wobec nich żadnych wątpliwości” (Tamże, s. 58). Dziecko w młodszym wieku szkolnym znajduje się w stadium relatywizmu moralnego.

L. Kohlberg natomiast wyróżnił trzy poziomy rozwoju moralnego: przedkonwencjonalny, konwencjonalny i postkonwencjonalny.

Według M. Łobockiego „Na poziomie przedkonwencjonalnym trudno jeszcze mówić - jego zdaniem - o moralności w ścisłym znaczeniu tego słowa, ponieważ postępowanie dziecka jest wtedy zależne głównie od uwarunkowań zewnętrznych" (Tamże, s. 59). Poziom ten przypada pomiędzy 2 a 7 rokiem życia.

Pojawia się zatem pytanie: Czy od dziecka w wieku wczesnoszkolnym, znajdującego się na poziomie moralności przedkonwencjonlanej, można wymagać umiejętności właściwego wartościowania? Dziecko w fazie rozwoju na poziomie moralności przedkonwencjonalnej nie jest jeszcze zdolne do wytworzenia właściwej hierarchii wartości, jednakże nauczyciel może podejmować pierwsze próby, aby wychowanek poznawał i na miarę swoich możliwości rozwojowych internalizował określone wartości.

Zatem, wyposażenie uczniów w umiejętności wartościowania siebie i otoczenia w aspekcie wartości religijnych stanowi dla nauczyciela ważne zadanie, bowiem w przyszłości będzie ono podstawą własnych wyborów, ocen moralnych, odkrywania prawdziwych wartości, budowania własnego systemu będącego podstawą aksjologiczną życia ucznia (Chałas, 2009). Należy wprowadzać dzieci w świat wartości tak, aby w przyszłości potrafiły być osobami samodzielnymi i odpowiedzialnymi, a ich decyzje życiowe rzutujące na ich przyszłość, były solidne i przemyślane, mające oparcie we własnej, właściwej hierarchii wartości.

Doświadczenia, przeżycia i wartości, zdobywane w procesie nauczania religii w edukacji wczesnoszkolnej, rozwijają u dziecka myślenie pojęciowe, obrazowe, wyobraźnię, ciekawość poznawczą i zainteresowania religijne. Dynamizują także proces poznania i wartościowania siebie jako osoby, poszerzają u dziecka horyzont umysłowy, integrują myśli, emocje i zachowania. Dzięki nim dziecko jest zdolne zaangażować się w życie wspólnotowe i społeczne grupy klasowej oraz szkolnej. Wzorem takiej trwałej wspólnoty będzie dla ucznia jego osobista relacja z Bogiem, na bazie której wzrastają inne wspólnoty ukierunkowane na tworzenie dobra wspólnego, aby świat czynić lepszym. Jan Paweł II podkreślał, iż: wiara nie może być przeżywana tylko we wnętrzu ludzkiego ducha. Ona musi znajdować swój wyraz w życiu zewnętrznym ( Jan Paweł II, 1999). 
Uczeń, przyswajając wartości religijne na katechezie, powinien być w przyszłości tym, który będzie niósł światło Chrystusa w życie społeczne: obszary kultury, ekonomii i polityki. Dlatego też Jan Paweł II przywiązywał tak wielką wagę do nauczania religii, jako podstawy budowania chrześcijańskiej kultury i wartości w dziedzictwie europejskim. Mówił: „Z nauczaniem religii, przede wszystkim religii katolickiej, w większości krajów europejskich wiąże się ogromny wkład Kościoła i poszczególnych państw. Należy uświadomić sobie, że z tego względu obejmuje ona młode pokolenia - dzieci i młodzież - oraz że jego treść jest wyrazem odniesienia do religijnego wymiaru życia ludzkiego, musi być ono uznane za pierwszorzędny wkład w budowanie Europy otwartej na dziedzictwo chrześcijańskiej kultury, które jest dziedzictwem Europy Wschodniej i Zachodniej”(Jan Paweł II, 1999).

Podsumowując, w nauczaniu religii w edukacji wczesnoszkolnej zadaniem nauczyciela jest, aby wychowanek, poznając wartości religijne w procesie edukacyjno-wychowawczym, stał się świadkiem Chrystusa Zmartwychwstałego, z odwagą pokonywał trudności, jakie niesie życie, budował cywilizację miłości w życiu osobistym i wspólnotowym, rozwijał się zgodnie z poziomem swojego rozwoju moralnego i integrował poprzez urzeczywistnianie na miarę swoich możliwości, takich wartości, jak: prawda, dobro, mądrość, miłość bliźniego, służba drugiemu, poszanowanie życia ludzkiego. Aby budował i doświadczał integralności wiary, życia, kultury i refleksji nad własną egzystencją.

To wartości religijne, przyswojone w procesie edukacyjno-wychowawczym i urzeczywistnione $\mathrm{w}$ życiu codziennym wychowanka, pozwolą mu na pełniejsze interpretowanie rzeczywistości, uczynią go dojrzalszym i bardziej odpowiedzialnym za siebie, drugiego człowieka, świat i przyszłość, jaka się przed nim otwiera. Dziecko w przyszłości stanie się odpowiedzialnym obywatelem i współtwórcą otaczającego go świata, pozwoli na stawianie przez niego ważnych pytań i szukania odpowiedzi na nie, w tym systemie wartości religijnych, jaki poznał podczas procesu edukacyjnego i uznał za swój własny. Ta hierarchia wartości będzie dla ucznia-wychowanka oparciem szczególnie w sytuacjach życiowo ważnych, doniosłych, a także trudnych, z którymi skonfrontuje go życie i otaczający go świat. 


\section{BIBLIOGRAFIA}

Chąas, K. (2003). Wychowanie ku wartościom. Elementy teorii i praktyki. T. 1. Godność, wolność, odpowiedzialność, tolerancja. Lublin-Kielce: Wydawnictwo Jedność.

ChAŁAS, K. MAJ, A. MARIAŃSKI, J. (2009). Wychowanie ku wartościom religijnym. Elementy teorii i praktyki. T. 4. Religia, wiara, nadzieja, miłość, modlitwa, świętość. Lublin-Kielce: Wydawnictwo Jedność.

DeneK, K (2005). Ku dobrej edukacji. Toruń-Leszno: Wydawnictwo Edukacyjne Akapit.

JAN PAwet II. (1999). Homilia w czasie Mszy św. odprawionej w Legnicy 2 VII 1997. W: Pielgrzymki do Ojczyzny. Przemówienia i homilie. Kraków.

JAN PAWEŁ II. Przemówienie do katechetów, nauczycieli i uczniów. Włocławek 6 VI 1991. W: Tamże.

Kunowski, S. (2004). Podstawy wspótczesnej pedagogiki. Warszawa: Wydawnictwo Salezjańskie.

ŁOBOCKI, M. (2002). Wychowanie moralne w zarysie. Kraków.

MalickA, M. (1999). Dać ludziom pragnienie. W: K. OlBRYChT (red.), Edukacja aksjologiczna. T. 4. Katowice: Wydawnictwo UŚ.

MiLerSKI, B. (2010). Pedagogika religii. W: B. ŚLIWERSKI (red.), Pedagogika. Subdyscypliny i dziedziny wiedzy o edukacji (s. 62.). Gdańsk: Gdańskie Wydawnictwo Pedagogiczne.

OLEŚ, P. (1983). System klaryfikacji wartości: założenia, zastosowanie, przegląd niektórych technik. Roczniki Filozoficzne, 31,4,63.

Ostrowska, U. (2006). Aksjologiczne podstawy wychowania, W: B. ŚLIWERSKI (red.), Pedagogika. Gdańsk: Gdańskie Wydawnictwo Pedagogiczne.

NowaK, M. (1999). Podstawy pedagogiki otwartej. Lublin: RW KUL.

NowAK, M. (2008). Teorie i koncepcje wychowania. Warszawa: Wydawnictwa Akademickie i Profesjonalne.

SCHRADE, U. (1992). Etyka - główne systemy. Warszawa: Redakcja Wydawnictw Oświatowych DSP Unia-Press.

WoŁosıuk, B. (2010). Wychowanie do wartości w edukacji wczesnoszkolnej. Lublin: Wydawnictwo KUL.

WoŁosıuK, B. (2012). Komunikacja interpersonalna w rodzinie w kontekście wychowania dzieci do wartości. W: M. JeZIORAŃsKi, D. OpOZDA, A. Rynio (red.), Rodzina przestrzeniq rozwoju osoby. Perspektywa pedagogiczna. Lublin: Towarzystwo Naukowe KUL.

\section{PRZESTRZEŃ AKSJOLOGICZNA W NAUCZANIU RELIGII DZIECI W WIEKU WCZESNOSZKOLNYM}

\section{Streszczenie}

Czas nauki dziecka w wieku wczesnoszkolnym to czas intensywnej pracy intelektualnej i duchowej, czas poznawania głębiej wartości religijnych. Niesie on ze sobą wiele zmian w życiu dziecka osobistym, rodzinnym i szkolnym. Niniejszy artykuł jest próbą odpowiedzi na pytanie:, w jaki sposób wartości religijne poszerzają przestrzeń aksjologiczną małego dziecka? W kontekście tego ogólnego pytania zostały sformułowane pytania szczegółowe: w jaki sposób nauczanie religii w edukacji wczesnoszkolnej wprowadza dziecko w świat tych wartości? jaka jest rola nauczyciela na tym etapie edukacyjnym w poszerzaniu przestrzeni aksjologicznej?

Słowa kluczowe: wartości religijne; rodzina; wychowanie; katecheza; edukacja wczesnoszkolna. 


\section{AXIOLOGICAL SPACE \\ OF TEACHING RELIGION TO EARLY SCHOOL CHILDREN}

S u m m a r y

The time of early education of a child in school is a time of intense intellectual and spiritual work. It carries a lot of changes in the child's personal, family and school life. This article is giving the attention to the problem of values in the child's life. It is also an attempt to answer the following questions: how does the time of early education introduce a child in early school age to the world of religious values, what is the role of the family and teachers during this period.

Key words: religious values; family; upbringing; catechesis; early education. 